\title{
Compared Lighting of Fluorescent Lamps with that LED devices for optimal habitability of classrooms
}

DOI: $10.46932 / \mathrm{sfjdv2n1-076}$

Received in: November 1st, 2020

Accepted in: December 30th, 2020

\author{
Oscar Enrique Tang Cruz \\ UNALM, Lima, Perú \\ otang@lamolina.edu.pe \\ Luis Shuseki Yoza Yoza \\ UNALM, Lima, Perú \\ lyoza@lamolina.edu.pe \\ Hernan Oscar Cortez Gutierrez \\ UNAC, Callao, Perú \\ hocortezg@unac.edu.pe \\ Ricardo Otilio Verde Vera \\ UNALM, Lima, Perú \\ ricardovera@lamolina.edu.pe \\ Juan Manuel Pesantes Rojas \\ UNALM, Lima, Perú \\ jmpesantes@lamolina.edu.pe \\ Eusebio Idelmo Cisneros Tarmeño \\ UNALM, Lima, Perú \\ ecisneros@lamolina.edu.pe \\ Jorge Luis Lozano Rodriguez \\ UNSCH, Ayacucho, Perú \\ jorge.lozano@unsch.edu.pe
Milagros Rocio Menacho Angeles
UPCH, Lima, Perú
mmenachoa@gmail.com
John Daniel Tang Cruz
UNT, Trujillo, Perú
johndanieltangcruz@gmail.com

\begin{abstract}
One of main shortcomings, frequently found, in national university classrooms is their deficient and insufficient lighting, and the quality of the devices that produce it, mostly of the fluorescent type, which are not without significant physiological drawbacks, including their harmful effect on the optic nerve of users, when its application is continuous and long term. This research was limited only to the aspect of sufficient and appropriate lighting of the classroom, moreover, it did so from the perspective of the type
\end{abstract}


of lamp or luminaire most convenient for the optimal lighting of the UNALM classrooms, according to the current state of lighting technology, identified the factors that make it possible to maximize the degree of pedagogical habitability of the UNALM classrooms, and also minimization of their environmental impact and their concomitant energy cost.

Keywords: pedagogical habitability, LED lighting, fluorescent lighting, optic nerve, sustainability.

\section{INTRODUCTION}

The great existing deficiencies in the pedagogical habitability of university classrooms are well known in Peru, be they of the so-called national universities or private ones. Known are also the main causes of its unsatisfactory current state: The mercantile nature, fundamentally unplanned, of university higher education in the country. The predominance of competitive market methods in the management of these without supervision or long-term plans, leads them to frequently change their order of priorities, postponing the attention due to students and teachers and also to the equipment of the classrooms, and laboratories, giving preference to inorganic institutional growth, driven by profits. The result of this is the so-called "inclusive exclusion" of the new graduate professional: without occupation according to their degree or connection with the economic and institutional activity of their region.

In these conditions, the low quality of pedagogical habitability proposed to the country's students contributes to making it more difficult for them to access a multifaceted, theoretical-practical and balanced education, which really enables them to obtain quality placements at the national or international level.

The really existing degree of pedagogical habitability is experienced more acutely by the last links in the chain: the teacher and his students. They verify on a daily basis that their classrooms are not "dwellings" in the welcoming sense given to them by the German philosopher Martin Heidegger, but rather transitory and impersonal habitats of outdated teaching and learning, mainly verbalistic and supported by notes, with significant shortages of books and equipment that they require electrical energy (for example, the electronic board), which is supplied, more badly than well, in this area. One of the main shortcomings, frequently found, in national university classrooms is their deficient and insufficient lighting, and the quality of the devices that produce it, mostly of the fluorescent type, which are not without significant physiological drawbacks, including their Harmful effect on the optic nerve of users, when its application is continuous and long-term, which occurs to a certain extent with night students in classrooms and workshops.

\section{MATERIALS AND METHODS}

\subsection{DATA COLLECTION TECHNIQUES AND INSTRUMENTS}

The measurement instruments and the techniques for using the measured data have been: 
- Questionnaire - 1 to students (25) about the available lighting.

- Questionnaire - 2 to teachers (5) on the available lighting.

- Prospective survey of experts (5) on performance of the LED system.

- Morphology of the current pedagogical habitability of the classrooms (by the author).

- Technical Sheet $\mathbf{- 1}$ with data of the current lighting system.

- Technical Sheet $\mathbf{- 2}$ with data on average energy consumption and costs.

\subsection{DATA PROCESSING TECHNIQUES}

In this section, the treatments that have been applied to the field information collected in various research scenarios through surveys, observation and measurement, by experts, teachers and students, whose handwritten and unpublished answers are found in ANNEXES section of this research. The treatments to this information are shown sequentially below.

The responses to the Survey, provided by the five (5) experts, whose personal data appear in Annex 2 of this document, were expurgated, ordered and tabulated, question by question, and then statistically processed, as follows:

\section{VARIABLE (X) SECTION 2, FOR EXPERTS:}

QUESTION 1: What is the type of lighting required by the UNALM classrooms?

Table $\mathrm{N}^{\mathrm{o}}$ 1: ANSWERS OF THE EXPERTS TO QUESTION NO. 1, VAR (X)

\begin{tabular}{|c|c|c|c|c|c|}
\hline Expert $N^{\mathbf{0}}$ & LED Total & $\begin{array}{c}\text { LED Classrooms } \\
\text { FLR Exteriors }\end{array}$ & LED Exteriors & FLR Total & INC Total \\
\hline $\mathbf{1}$ & & $\mathbf{X}$ & & & \\
$\mathbf{2}$ & & $\mathbf{X}$ & & & \\
$\mathbf{3}$ & & $\mathbf{X}$ & & \\
$\mathbf{4}$ & $\mathbf{X}$ & & & \\
$\mathbf{5}$ & & $\mathbf{X}$ & & & \\
\hline
\end{tabular}

NOTE: LED = Emitting Diode / FLR = Fluorescent $/$ INC = Incandescent

This table contains information of an estimative type (subjective preference, but informed by the knowledge and experience of the five experts). The answer has two aspects: The preferable lighting technology, and the environment where it should be installed, marked with an X (Capital Letter). It is clear that the experts prefer, all of them, the LED lighting and the area where it should be installed: In all the classrooms of the University Campus. All other areas of the University must continue with 
Fluorescence Lighting (FLR) Clearly the underlying idea of the experts is to start modernizing lighting, but in stages, the first of which is unanimously identified: LED and FLUORESCENT.

QUESTION2: What is the ergonomic quality of the lighting system in UNALM classrooms? This with respect to Optimal Quality $=100 \%$

Table N²: ANSWERS BY THE EXPERTS TO QUESTION NO. 2, VAR (X)

\begin{tabular}{|c|c|}
\hline Expert $\mathrm{N}^{\mathrm{o}}$ & Ergonomic quality \\
\hline $\mathbf{1}$ & $\mathbf{7 0} \%$ \\
$\mathbf{2}$ & $\mathbf{4 0} \%$ \\
$\mathbf{3}$ & $\mathbf{5 0} \%$ \\
$\mathbf{4}$ & $\mathbf{4 0} \%$ \\
$\mathbf{5}$ & $\mathbf{7 0 \%}$ \\
\hline
\end{tabular}

This table contains information of an estimative type (informed evaluation of the experts): about the ergonomic quality of the current lighting system of the classrooms of this university for the visual work of the students. It is clear that experts recognize that this ergonomics is well below optimal and this in all classrooms.

The statistical work table, with the calculated values of the mean and standard deviation of the collected data, showed the following aspect:

Average level of ergonomics evaluated $=\mathbf{5 4 \%}$

Probability $=\mathbf{0 . 9 5}$ (established as the confidence level of this test)

Expected deviation $\mathbf{1 5 . 2 \%}$

Ergonomic expected value range, with $95 \%$ safety $=\mathbf{5 4 \%} \pm \mathbf{1 5 . 2 \%}$

QUESTION 3: What is the average Pedagogical Habitability observed in the UNALM classrooms? This with respect to the Optimal Pedagogical Habitability $=100 \%$

Table N³: ANSWERS OF THE EXPERTS TO QUESTION NO. 3, VAR (X)

\begin{tabular}{|c|c|}
\hline Expert $^{\circ}$ & Pedagogical Habitability \\
\hline $\mathbf{1}$ & $\mathbf{5 0} \%$ \\
$\mathbf{2}$ & $\mathbf{5 0} \%$ \\
$\mathbf{3}$ & $\mathbf{5 0} \%$ \\
$\mathbf{4}$ & $\mathbf{5 0} \%$ \\
$\mathbf{5}$ & $\mathbf{7 0 \%}$ \\
\hline
\end{tabular}

This table contains the measurement made, by the five experts, of the Habitability of the classrooms in question, which should be seen as the result of the technological components of safety, comfort with individual furniture and the use of devices by students. 
The statistical work table, with the calculated values of the mean and standard deviation, showed the following aspect:

Average expected value $=\mathbf{5 4 \%}$

Probability $=\mathbf{0 . 9 5}$ (established as the confidence level of this test)

Expected deviation $=\mathbf{8 . 9 \%}$

Expected value range, with $95 \%$ certainty $=\mathbf{5 4 \%} \pm \mathbf{8 . 9 \%}$

QUESTION 4: What is the current energy sustainability of the UNALM lighting system, estimated between 5 percentage values, taking Optimal Habitability $=\mathbf{1 0 0 \%}$ as a reference?

Table No4: ANSWERS FROM THE EXPERTS TO QUESTION NO. 4, VAR (X)

\begin{tabular}{|c|c|}
\hline Expert $\mathrm{N}^{\circ}$ & Energy Sustainability \\
\hline $\mathbf{1}$ & $\mathbf{7 0} \%$ \\
$\mathbf{2}$ & Hard to estimate \\
$\mathbf{3}$ & $\mathbf{6 7} \%$ \\
$\mathbf{4}$ & $\mathbf{6 7} \%$ \\
$\mathbf{5}$ & Hard to estimate \\
\hline
\end{tabular}

This table contains the measurement made by the Sustainability experts in question, which refers fundamentally to the capacity of the university's electrical system to economically meet not only the University's electrical energy needs, but also to do so while minimizing use. of polluting fuels, not allowing failures or undue stoppages, thanks to the high level of Maintenance without exceptions and throughout the entire useful life of this system. Clean electrical power at the service of student teachinglearning.

The statistical work table, with the calculated values of the mean and standard deviation, showed the following aspect:

Average expected value $=67 \%$

Probability $=\mathbf{0 . 9 5}($ established as the confidence level of this test)

Expected deviation $=0.0 \%$

Expected value range, with $95 \%$ certainty $=\mathbf{6 7 \%} \pm \mathbf{0 . 0 \%}$

QUESTION 5: What is the current degree of economic sustainability of the UNALM lighting system? This with respect to Optimal economic Sustainability $=100 \%$ 
Table No5: ANSWERS OF THE EXPERTS TO QUESTION No. 5. VAR (X)

\begin{tabular}{|c|c|}
\hline Expert $\mathrm{N}^{\circ}$ & Energy Sustainability \\
\hline $\mathbf{1}$ & $\mathbf{8 0} \%$ \\
$\mathbf{2}$ & Hard to estimate \\
$\mathbf{3}$ & $\mathbf{8 0} \%$ \\
$\mathbf{4}$ & $\mathbf{7 0} \%$ \\
$\mathbf{5}$ & $\mathbf{7 0} \%$ \\
\hline
\end{tabular}

This table contains the measurements made by the Sustainability experts in question, which should be seen as the result of the value of the salaries of the staff, the technological cost components of the facilities and the maintenance of the set of equipment, lines and existing lights in classrooms, Laboratory and Library, etc.

The statistical work table, with the calculated values of the mean and standard deviation, showed the following aspect:

Average expected value $=\mathbf{7 5 \%}$

Probability $=\mathbf{0 . 9 5}$ (established as the confidence level of this test)

Expected deviation $=\mathbf{5 . 0 \%}$

Expected value range, with $95 \%$ certainty $=\mathbf{7 5 \%} \pm \mathbf{5 . 0 \%}$

\section{VARIABLE (Y) SECTION 1, FOR STUDENTS AND TEACHERS:}

QUESTION 1: What is the predominant lighting technology observed by the students (and teachers) of UNALM?

Table N6: STUDENTS 'RESPONSES TO QUESTION No. 1, VAR (Y)

\begin{tabular}{|c|c|c|c|c|c|}
\hline $\begin{array}{c}\mathrm{N}^{\circ} . \text { Students } \\
\text { who answered }\end{array}$ & LED Total & FLR Total & FLR + INC & LED en Lab. & $\begin{array}{c}\text { LED Classrooms } \\
\text { INC. Exterior }\end{array}$ \\
\hline $\mathbf{4 0}$ de $\mathbf{4 4}$ & $\mathbf{4}$ & $\mathbf{2 3}$ & $\mathbf{1 1}$ & $\mathbf{1}$ & $\mathbf{1}$ \\
\hline
\end{tabular}

NOTE: See the individual sheets of each student in the ANNEXES Section

Table No 8: TEACHERS 'RESPONSES TO QUESTION NO. 1, VAR (Y)

\begin{tabular}{|c|c|c|c|c|c|}
\hline $\begin{array}{c}\mathrm{N}^{\mathbf{o}} \text { Teachers who } \\
\text { answered }\end{array}$ & LED Total & FLR Total & FLR + INC & LED en Lab. & $\begin{array}{c}\text { LED Classrooms } \\
\text { INC. Exterior }\end{array}$ \\
\hline $\mathbf{5}$ de $\mathbf{5}$ & $\mathbf{0}$ & $\mathbf{5}$ & $\mathbf{0}$ & $\mathbf{0}$ & $\mathbf{0}$ \\
\hline
\end{tabular}

NOTE: See the individual sheets of each teacher in the ANNEXES Section

These last two tables are descriptive (individual observation of students and teachers). The answer shows an important aspect: Recognition of the lighting technology observed. There are 6 cases of students who show they are unaware of LED lighting. Teachers recognize all lighting technologies without error: 
$\mathbf{5 3 \%}$ of the 43 students affirm that the lighting technology at UNALM is basically FLUORESCENT, the rest basically INCANDESCENT.

$\mathbf{1 0 0 \%}$ of the 5 professors affirm that the lighting technology at UNALM is basically FLUORESCENT, which is correct

The difference in perception between the two groups can be attributed mainly to the better discernment and technological knowledge of teachers and experts

QUESTION 2: What is the type of lighting that predominates in the UNALM classrooms, estimated as a percentage with respect to all (100\%) of existing lighting devices: INC spotlights, FLR lamps, etc. Observed by UNALM students and teachers?

Table $N^{\circ}$ 9: STUDENTS 'RESPONSES TO QUESTION No. 2, VAR (Y)

\begin{tabular}{|c|c|c|c|c|c|}
\hline $\begin{array}{c}\mathrm{N}^{\mathrm{o}} \text {.of students } \\
\text { who answered }\end{array}$ & INC lightening & FLR Lamps & LED lightening & LED Panels & FLR Saving bulbs \\
\hline $\mathbf{4 4}$ & $\mathbf{2 3}$ & $\mathbf{4 4}$ & $\mathbf{0}$ & $\mathbf{0}$ & $\mathbf{0}$ \\
\hline
\end{tabular}

NOTE: See the individual sheets of each student in the ANNEXES Section

Table No 10: TEACHERS 'ANSWERS TO QUESTION NO. 2, VAR (Y)

\begin{tabular}{|c|c|c|c|c|c|}
\hline $\begin{array}{c}\mathrm{N}^{\mathbf{o}} \text { Teachers who } \\
\text { answered }\end{array}$ & LED Total & FLR Total & FLR + INC & LED en Lab. & $\begin{array}{c}\text { LED Classrooms } \\
\text { INC. Exterior }\end{array}$ \\
\hline $\mathbf{5}$ de 5 & $\mathbf{0}$ & $\mathbf{5}$ & $\mathbf{0}$ & $\mathbf{0}$ & $\mathbf{0}$ \\
\hline
\end{tabular}

NOTE: See individual sheets for each teacher in the ANNEXES Section

These two tables are descriptive (individual observation of students and teachers). The answer has an important aspect: Recognition of the lights currently observed at UNALM, the fluorescent tubes and, very secondarily, the incandescent bulbs.

QUESTION 3: What is the ergonomic quality of the lighting system observed in the UNALM classrooms? This with respect to the Optimal Ergonomic Quality $=100 \%$

Table $\mathrm{N}^{\circ}$ 11: STUDENTS 'RESPONSES TO QUESTION No. 3, VAR (Y)

\begin{tabular}{|c|c|}
\hline Students $\Sigma=45$ & Ergonomic Quality Grade of S. I. \\
\hline $\mathbf{5}$ & $\mathbf{1 5 \%}$ \\
$\mathbf{5}$ & $\mathbf{3 0} \%$ \\
$\mathbf{1 1}$ & $\mathbf{4 0 \%}$ \\
$\mathbf{1 2}$ & $\mathbf{5 0} \%$ \\
$\mathbf{1 2}$ & $\mathbf{2 0} \%$ \\
\hline
\end{tabular}

NOTE: See the individual sheets of each student in the ANNEXES Section 
From this table, of the histogram type, the final values for this question were calculated to the students:

Average expected value $\mathbf{= 3 3 . 2 \%}$

Probability $\mathbf{= 0 . 9 5}$ (established as the confidence level of this test)

Expected deviation $=\mathbf{1 3 . 5 \%}$

Expected value range, with $95 \%$ certainty $=\mathbf{3 3 . 2} \% \pm \mathbf{1 3 . 5} \%$

Table N 12: TEACHERS 'RESPONSES TO QUESTION No. 3, VAR (Y)

\begin{tabular}{|c|c|}
\hline Teacher $\mathrm{N}^{\mathrm{o}}$ & Ergonomic Quality Grade of S. I. \\
\hline $\mathbf{1}$ & $\mathbf{1 5 \%}$ \\
$\mathbf{2}$ & $\mathbf{3 0} \%$ \\
$\mathbf{3}$ & Hard to estimate \\
$\mathbf{4}$ & $\mathbf{3 0} \%$ \\
$\mathbf{5}$ & $\mathbf{3 0} \%$ \\
\hline
\end{tabular}

NOTE: The teacher's number is the one on his answer sheet

From this table, of the histogram type, the final values were calculated for this question to the teachers:

Average expected value $\mathbf{=} \mathbf{2 1 . 0 \%}$

Probability $=\mathbf{0 . 9 5}$ (established as the confidence level of this test)

Expected deviation $\mathbf{1} \mathbf{1 3 . 4 \%}$

Expected value range, with $95 \%$ certainty $=\mathbf{2 1 \%} \pm \mathbf{1 3 . 4 \%}$

QUESTION 4: What is the average pedagogical habitability, in percentage, observed in the UNALM classrooms? This with respect to Optimal Habitability $=100 \%$

Table No 13: STUDENTS 'RESPONSES TO QUESTION No. 4, VAR (Y)
\begin{tabular}{|c|c|}
\hline Students $\Sigma=45$ & Pedagogical Habitability \\
\hline $\mathbf{1}$ & $\mathbf{4 0 ~ \%}$ \\
$\mathbf{2}$ & $\mathbf{5 0} \%$ \\
$\mathbf{3}$ & $\mathbf{7 0} \mathbf{\%}$ \\
$\mathbf{4}$ & $\mathbf{1 0 0} \%$ \\
$\mathbf{5}$ & Hard to estimate \\
\hline
\end{tabular}
NOTE: See the individual sheets of each student in the ANNEXES Section

From this table the final values were calculated for this question to the students:

Average expected value $=\mathbf{6 5 \%}$

Probability $=\mathbf{0 . 9 5}$ (established as the confidence level of this test)

Expected deviation $=\mathbf{1 9 . 2 \%}$

Expected value range, with $95 \%$ certainty $=\mathbf{6 5 \%} \pm \mathbf{1 9 . 2 \%}$ 


Table No 14: TEACHERS 'RESPONSES TO QUESTION No
\begin{tabular}{|c|c|}
\hline Teacher $\Sigma=45$ & Pedagogical Habitability \\
\hline $\mathbf{1}$ & $\mathbf{7 0 \%}$ \\
$\mathbf{2}$ & $\mathbf{5 0 \%}$ \\
$\mathbf{3}$ & Hard to estimate \\
$\mathbf{4}$ & $\mathbf{7 0 \%}$ \\
$\mathbf{5}$ & $\mathbf{7 0 \%}$
\end{tabular}

NOTE: The teacher's number is the one on his answer sheet

From this table the final values were calculated for this question to the teachers:

Average expected value $\mathbf{= 6 5 . 0 \%}$

Probability $=\mathbf{0 . 9 5}$ (established as the confidence level of this test)

Expected deviation $\mathbf{= 7 . 7 \%}$

Expected value range, with $95 \%$ certainty $=\mathbf{6 5 \%} \pm \mathbf{7 . 7 \%}$

Note the great mutual consistency in the results of students and teachers, obtained separately and with different forms.

QUESTION 5: What is the degree of Energy Sustainability observed in the UNALM lighting system? This with respect to Optimal Sustainability $=100 \%$, achievable in theory through LED Technology

Table No 15: STUDENTS 'RESPONSES TO QUESTION No. 5, VAR (Y)

\begin{tabular}{|c|c|}
\hline Students $\Sigma=45$ & Economic sustainability \\
\hline $\mathbf{1}$ & Hard to estimate \\
$\mathbf{6}$ & $\mathbf{4 0} \%$ \\
$\mathbf{1 8}$ & $\mathbf{7 0} \%$ \\
$\mathbf{1 9}$ & $\mathbf{5 0} \%$ \\
$\mathbf{1}$ & $\mathbf{1 0 0} \%$ \\
\hline
\end{tabular}

NOTE: See the individual sheets of each student in the ANNEXES Section

From this table the final values were calculated for this question to the students:

Average expected value $\mathbf{= 5 6 . 6 \%}$

Probability $=\mathbf{0 . 9 5}$ (established as the confidence level of this test)

Expected deviation $=\mathbf{1 8 . 2 \%}$

Expected value range, with $95 \%$ certainty $=\mathbf{5 6 . 6 \%} \pm \mathbf{1 8 . 2 \%}$ 
Table No 16: TEACHERS 'RESPONSES TO QUESTION No. 5, VAR (Y)

\begin{tabular}{|c|c|}
\hline Teacher $^{\mathrm{o}}$ & Economic sustainability \\
\hline $\mathbf{1}$ & $\mathbf{5 0} \%$ \\
$\mathbf{2}$ & $\mathbf{5 0} \%$ \\
$\mathbf{3}$ & Hard to estimate \\
$\mathbf{4}$ & $\mathbf{5 0} \%$ \\
$\mathbf{5}$ & $\mathbf{5 0} \%$ \\
\hline
\end{tabular}

NOTE: The teacher's number is the one on his answer sheet

From this table the final values were calculated for this question to the teachers:

Average expected value $\mathbf{= 4 0 . 0 \%}$

Probability $=\mathbf{0 . 9 5}$ (established as the confidence level of this test)

Expected deviation $\mathbf{=} \mathbf{3 . 2 \%}$

Expected value range, with $95 \%$ certainty $=\mathbf{4 0 \%} \pm \mathbf{3 . 2 \%}$

The professors have a more critical concept than the students regarding the Pedagogical Habitability of the classrooms of this university. This is explained by its greater objectivity of judgment

\section{VARIABLE (W) SECTION 1, FOR THE EXPERTS:}

QUESTION 1: What is the lighting required by the UNALM classrooms?

Table N ${ }^{\circ}$ 17: ANSWERS OF THE EXPERTS TO QUESTION NO. 1, VAR (W)

\begin{tabular}{|c|c|c|c|c|c|}
\hline Expert N $^{\text {o }}$ & LED Total & $\begin{array}{c}\text { LED Classrooms } \\
\text { Outdoor FLR }\end{array}$ & Outdoor LEDs & FLR Total & INC Total \\
\hline $\mathbf{1}$ & & $\mathbf{X}$ & & & \\
$\mathbf{2}$ & & $\mathbf{X}$ & & \\
$\mathbf{3}$ & $\mathbf{X}$ & & \\
$\mathbf{4}$ & $\mathbf{X}$ & & \\
$\mathbf{5}$ & $\mathbf{X}$ & & \\
\hline
\end{tabular}

This table is also an estimate: The lighting that is preferred for the classrooms is certainly LED, but the exteriors should continue to be FLUORESCENT. Clearly the unanimous idea of the experts is to modernize the lighting, but in stages: It would start in Classrooms with LEDs and in Outdoors with FLUORESCENTS. There is a coincidence with the opinion of the students and teachers

QUESTION2: What is the type of lighting you prefer for UNALM? 
Table No 18: ANSWERS OF THE EXPERTS TO QUESTION NO. 2, VAR (W)

\begin{tabular}{|c|l|}
\hline Expert $\mathrm{N}^{\mathrm{o}}$ & \multicolumn{1}{c|}{ Type of luminaires for UNALM } \\
\hline $\mathbf{1}$ & LED PANELS in classrooms + fluorescent TUBES outdoors \\
2 & IDEM \\
3 & IDEM \\
\hline
\end{tabular}

This estimate table shows information consistent with that shown in the table of the previous question. Experts are in favor of changing luminaires starting with LED panels in classrooms and fluorescent tubes outdoors. There is only one discrepancy that prefers to go directly to the exclusive LED Panel for economic considerations.

QUESTION 3: What is the average luminosity (measured by luxmeter in Lumens/m²) per lamp in UNALM classrooms?

(Take note that the minimum regulated values to study are, between: 300 and 500 Lumens / $\mathrm{m} 2 \mathrm{in} \mathrm{LED}$ or fluorescent lamps)

Table N ${ }^{\text {o }}$ 19: ANSWERS OF THE EXPERTS TO QUESTION NO. 3, VAR (W)
\begin{tabular}{|c|l|}
\hline Expert N & Average brightness of lamps, measured in UNALM classrooms \\
\hline $\mathbf{1}$ & $\mathbf{1 1 0 0}$ lumens in classroom fluorescent tubes \\
$\mathbf{2}$ & $\mathbf{5 0}$ lumens in fluorescent tubes in laboratory \\
$\mathbf{3}$ & $\mathbf{9 6}$ lumens in classroom fluorescent tubes \\
$\mathbf{4}$ & $\mathbf{2 3 3}$ lumens in classroom fluorescent tubes \\
$\mathbf{5}$ & $\mathbf{4 0 0}$ lumens in fluorescent tubes in classrooms \\
\hline
\end{tabular}

NOTE: Compare with the national STANDARD, EM 010, which prescribes for "Reading rooms, classrooms, laboratories, workshops, gyms between $300 \mathrm{~A}$ - B and $500 \mathrm{~A}$ - B"

This table records the information on the real illumination that the texts of the students and professors receive with the fluorescent lights currently in use at UNALM This data was obtained by direct measurement by the experts, with the luxmeter provided by the university, and acting by shift and independently: It is deduced by simple inspection that the lighting in the UNALM classrooms barely reaches $33 \%$ of what it should be at least. A critical situation that should be corrected immediately.

From this table the final mean values were calculated for this question:

Average expected value $=\mathbf{1 9 5 . 8}$ lumens

Probability $=\mathbf{0 . 9 5}$ (established as the confidence level of this test)

Expected deviation $=\mathbf{1 2 6 . 8 \%}$

Expected value range, with $95 \%$ certainty $=\mathbf{1 9 5 . 8 \%} \pm \mathbf{1 2 6 . 8 \%}$ 
The high dispersion of the sample is surely explained by the great difference between the facilities of the UNALM classrooms with respect to the lighting they provide. In any case, it is clear that all the classrooms at this university are below the minimum lighting required, with $95 \%$ security.

QUESTION 4: What is the energy sustainability shown by the current UNALM lighting system? This is estimated as a percentage (\%) with respect to what would be expected from the LED lighting system, to which a $100 \%$ sustainability is conventionally attributed

Table N 20: ANSWERS OF THE EXPERTS TO QUESTION NO
\begin{tabular}{|c|c|}
\hline Expert N & Economic sustainability \\
$\mathbf{1}$ & $\mathbf{7 0} \%$ \\
$\mathbf{2}$ & Hard to estimate \\
$\mathbf{3}$ & $\mathbf{8 0} \%$ \\
$\mathbf{4}$ & $\mathbf{7 0} \%$ \\
$\mathbf{5}$ & Hard to estimate \\
\hline
\end{tabular}

From this table the final mean values were calculated for this question:

Average expected value $=\mathbf{7 3 . 3 \%}$

Probability $=\mathbf{0 . 9 5}$ (established as the confidence level of this test)

Expected deviation $=\mathbf{4 . 8 \%}$

Expected value range, with $95 \%$ certainty $=\mathbf{7 3 . 3 \%} \pm \mathbf{4 . 8 \%}$

The energy sustainability of UNALM lighting is therefore definitely below what it would have if the luminaires were LED, with $95 \%$ security

QUESTION 5: What is the degree of economic sustainability of the current lighting system at UNALM? Optimal economic sustainability is $\mathbf{1 0 0 \%}$ and can be conventionally attributed to the LED system.

Table No 21: ANSWERS OF THE EXPERTS TO QUESTIO
\begin{tabular}{|c|c|}
\hline Expert $N^{\circ}$ & Economic sustainability \\
\hline $\mathbf{1}$ & $\mathbf{8 0} \%$ \\
$\mathbf{2}$ & Hard to estimate \\
$\mathbf{3}$ & $\mathbf{8 0} \%$ \\
$\mathbf{4}$ & $\mathbf{7 0} \%$ \\
$\mathbf{5}$ & $\mathbf{7 0} \%$ \\
\hline
\end{tabular}

From this table the final mean values were calculated for this question:

Average expected value $\mathbf{=} \mathbf{7 5 . 0 \%}$

Probability $=\mathbf{0 . 9 5}$ (established as the confidence level of this test)

Expected deviation $\mathbf{= 5 . 0 \%}$ 
Expected value range, with $95 \%$ certainty $=\mathbf{7 5 . 0 \%} \pm \mathbf{5 . 0 \%}$

The economic sustainability of the current lighting of the UNALM, based on fluorescents, is therefore appreciably below the economic sustainability that it would have if the luminaires were LED. The reason is simple: The difference in energy efficiency leads to inescapable operating cost differences. This with $95 \%$ security.

Fig.1. a. Classroom with adequate lighting b. Classroom with inadequate lighting

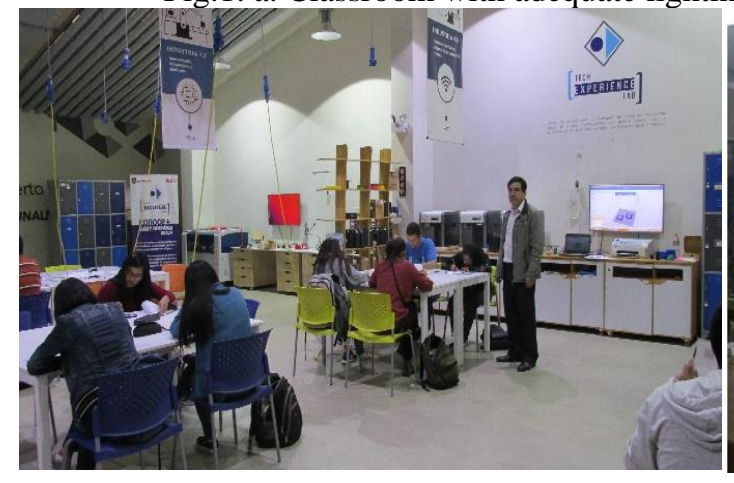

a)

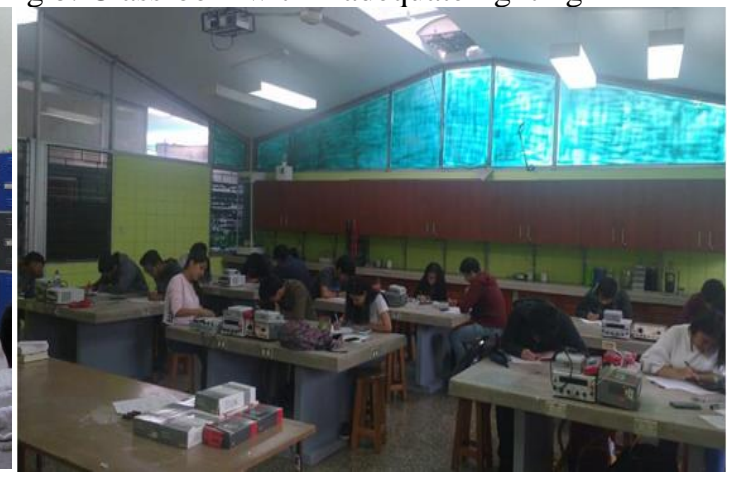

b)

Fig. 2. a. Analog multimeter b. Digital multimeter c. Luxmeter

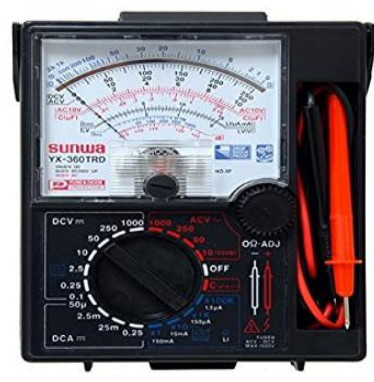

a)

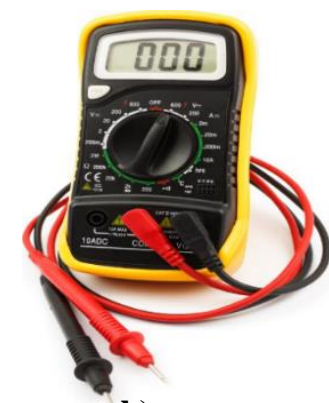

b)

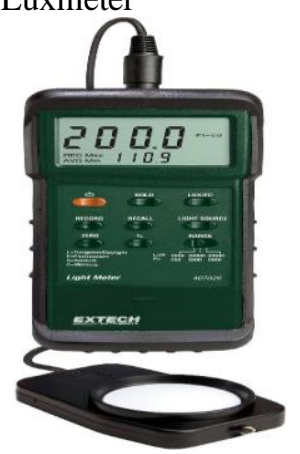

c)

\section{RESULTS AND DISCUSSION}

3.1 CONTRAST PROCESS OF THE HYPOTHESES BEFORE THE EXPERIMENT.

Table $\mathrm{N}^{\circ}$ 22: SCORE

\begin{tabular}{|c|c|c|c|}
\hline STUDENTS & SCORE & STUDENTS & SCORE \\
\hline $\mathbf{N}^{\circ}$ & CONTROL GROUP & $\mathbf{N}^{\circ}$ & EXPERIMENTAL GROUP \\
\hline 01 & $\mathbf{1 2}$ & 21 & $\mathbf{1 2}$ \\
\hline 02 & $\mathbf{1 2}$ & 22 & $\mathbf{1 1}$ \\
\hline 03 & $\mathbf{1 0}$ & 23 & $\mathbf{1 1}$ \\
\hline 04 & $\mathbf{1 2}$ & 24 & $\mathbf{1 2}$ \\
\hline 05 & $\mathbf{1 1}$ & 25 & $\mathbf{1 2}$ \\
\hline 06 & $\mathbf{1 2}$ & 26 & $\mathbf{1 0}$ \\
\hline
\end{tabular}




\begin{tabular}{|l|c|c|c|}
\hline 07 & $\mathbf{1 2}$ & 27 & $\mathbf{1 3}$ \\
\hline 08 & $\mathbf{1 0}$ & 28 & $\mathbf{1 1}$ \\
\hline 09 & $\mathbf{1 4}$ & 29 & $\mathbf{1 2}$ \\
\hline 10 & $\mathbf{1 3}$ & 30 & $\mathbf{1 1}$ \\
\hline 11 & $\mathbf{6}$ & 31 & $\mathbf{1 0}$ \\
\hline 12 & $\mathbf{1 2}$ & 32 & $\mathbf{1 0}$ \\
\hline 13 & $\mathbf{9}$ & 33 & $\mathbf{1 4}$ \\
\hline 14 & $\mathbf{1 0}$ & 34 & $\mathbf{1 5}$ \\
\hline 15 & $\mathbf{1 1}$ & 35 & $\mathbf{1 2}$ \\
\hline 16 & $\mathbf{8}$ & 36 & $\mathbf{1 3}$ \\
\hline 17 & $\mathbf{1 2}$ & 37 & $\mathbf{1 1}$ \\
\hline 18 & $\mathbf{8}$ & 38 & $\mathbf{1 2}$ \\
\hline 19 & $\mathbf{1 0}$ & 39 & $\mathbf{1 2}$ \\
\hline 20 & $\mathbf{1 2}$ & 40 & \\
\hline
\end{tabular}

\section{GENERAL HYPOTHESIS}

Table $\mathrm{N}^{\mathrm{O}}$ 23: STATISTICS OBTAINED IN THE PRE-TEST OF THE G.C AND G.E.

\begin{tabular}{|l|c|c|c|}
\hline \multicolumn{2}{|l|}{ STATISTICAL } & G. CONTROL & G. EXPERIMENTAL \\
\hline $\mathrm{N}^{\circ}$ & Valid & 20 & 20 \\
\hline \multicolumn{2}{|c|}{ Average $(\overline{\mathrm{X}})$} & 10.80 & 11.80 \\
\hline \multicolumn{2}{|c|}{ Median $(\mathrm{Me})$} & 11.50 & 12 \\
\hline \multicolumn{2}{|c|}{ Moda $\left(\mathrm{M}_{0}\right)$} & 12 & 12 \\
\hline \multicolumn{2}{|c|}{ Dev. typ. $(\mathrm{S})$} & 1.936 & 1.281 \\
\hline \multicolumn{2}{|c|}{ Variance $\left(\mathrm{S}^{2}\right)$} & 3.747 & 1.642 \\
\hline \multicolumn{2}{|c|}{ Minimum $\left(\mathrm{X}_{\mathrm{m}}\right)$} & 06 & 10 \\
\hline \multicolumn{2}{|c|}{ Maximum $\left(\mathrm{X}_{\mathrm{M}}\right)$} & 14 & 15 \\
\hline
\end{tabular}

\section{Graphic $\mathbf{N}^{\circ} 01$}

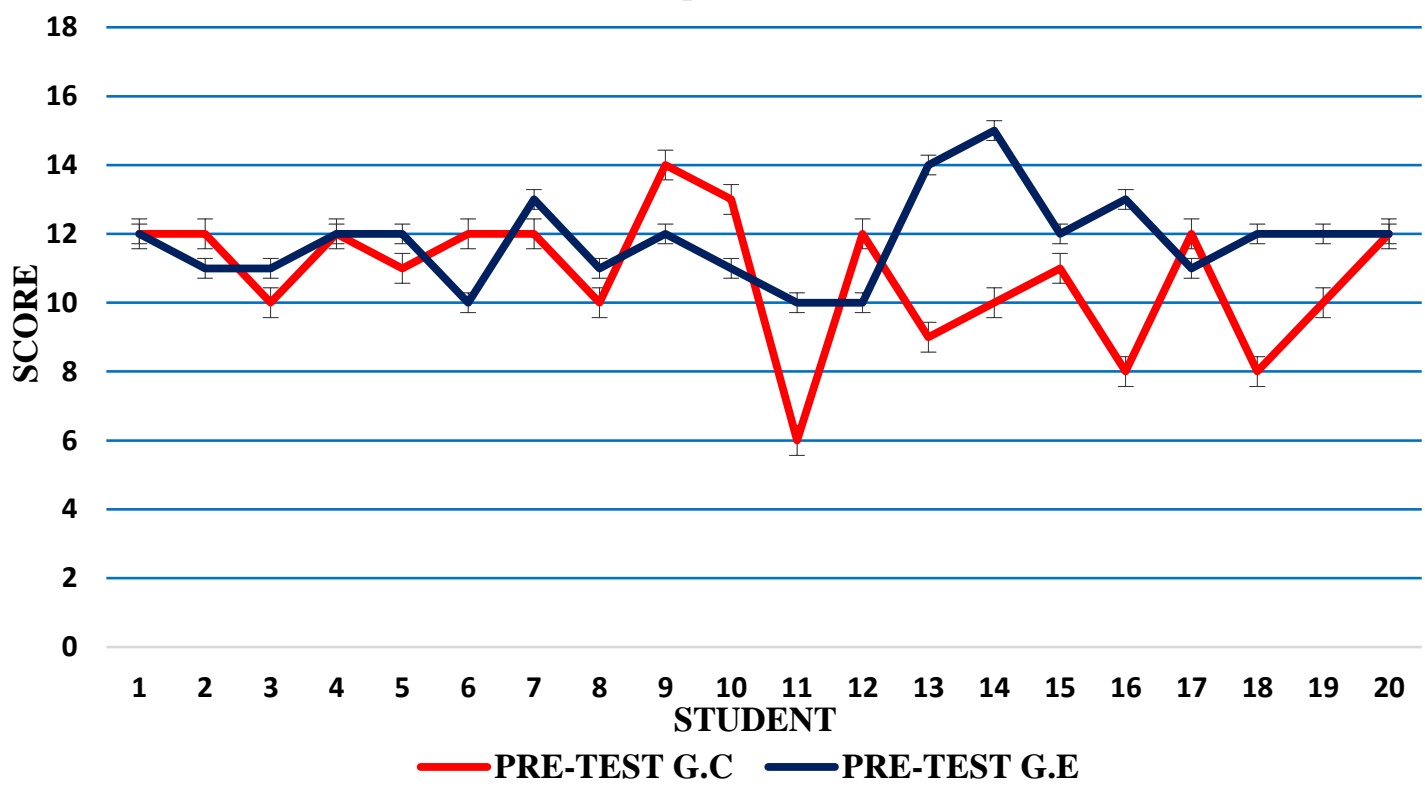


Fig. 6. Wind turbine monitoring system

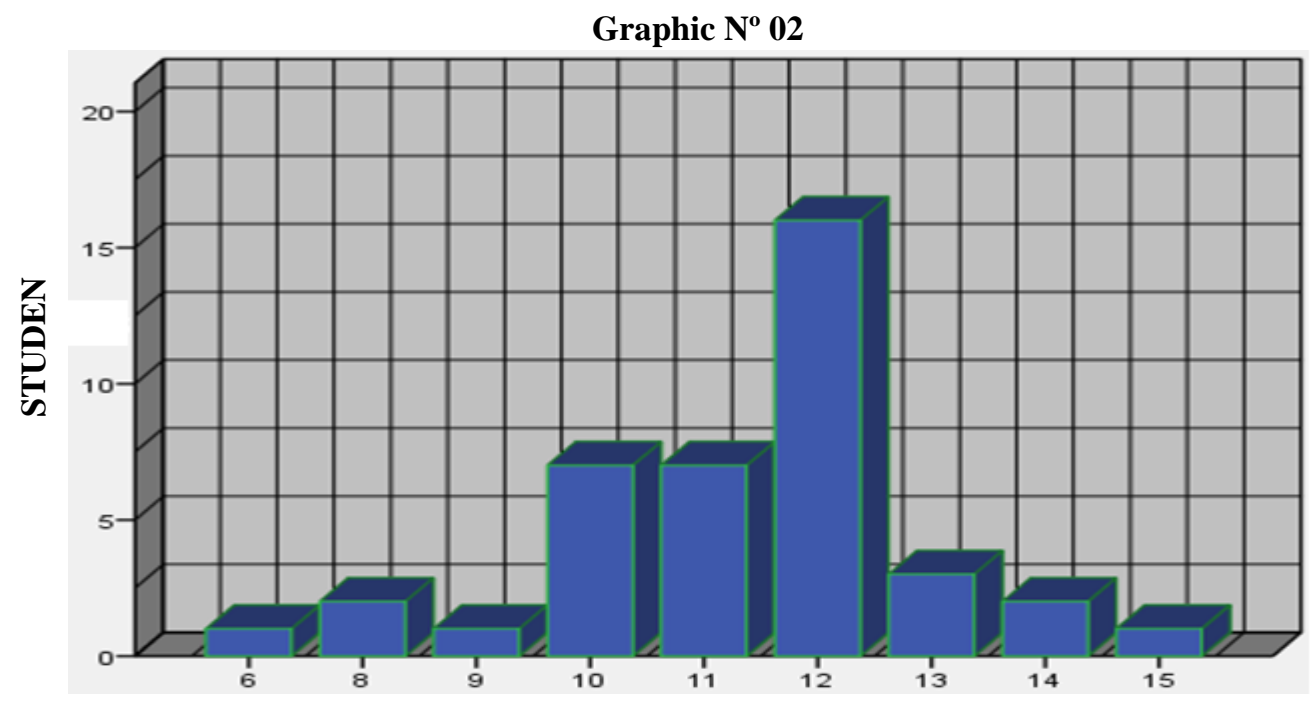

SCORE

Table ${ }^{\circ}$ 24: GRADES OBTAINED IN THE PRE-TEST OF THE LEARNING OF MEASUREMENT DIMENSIONS WITH ANALOGUE (I.A) AND DIGITAL (I.D) INSTRUMENTS

\begin{tabular}{|c|c|c|c|c|}
\hline \multirow{2}{*}{ LEARNING } & \multicolumn{3}{|c|}{ DIMENSION } \\
\cline { 2 - 5 } & I.A & I.D & TOTAL \\
\hline \multirow{2}{*}{ DEFICIENT } & $\mathrm{N}^{\circ}$ Students & 8 & 3 & 11 \\
\cline { 2 - 5 } & $\%$ & $72.7 \%$ & $27.3 \%$ & $100.0 \%$ \\
\hline \multirow{2}{*}{ REGULAR } & $\mathrm{N}^{\circ}$ Students & 10 & 16 & 26 \\
\cline { 2 - 5 } & $\%$ & $38.5 \%$ & $61.5 \%$ & $100.0 \%$ \\
\hline \multirow{2}{*}{ GOOD } & $\mathrm{N}^{\circ}$ Students & 2 & 1 & 3 \\
\cline { 2 - 5 } & $\%$ & $66.7 \%$ & $33.3 \%$ & $100.0 \%$ \\
\hline \multirow{2}{*}{ TOTAL } & $\mathrm{N}^{\circ}$ Students & 20 & 20 & 40 \\
\cline { 2 - 5 } & $\%$ & $50.0 \%$ & $50.0 \%$ & $100.0 \%$ \\
\hline
\end{tabular}

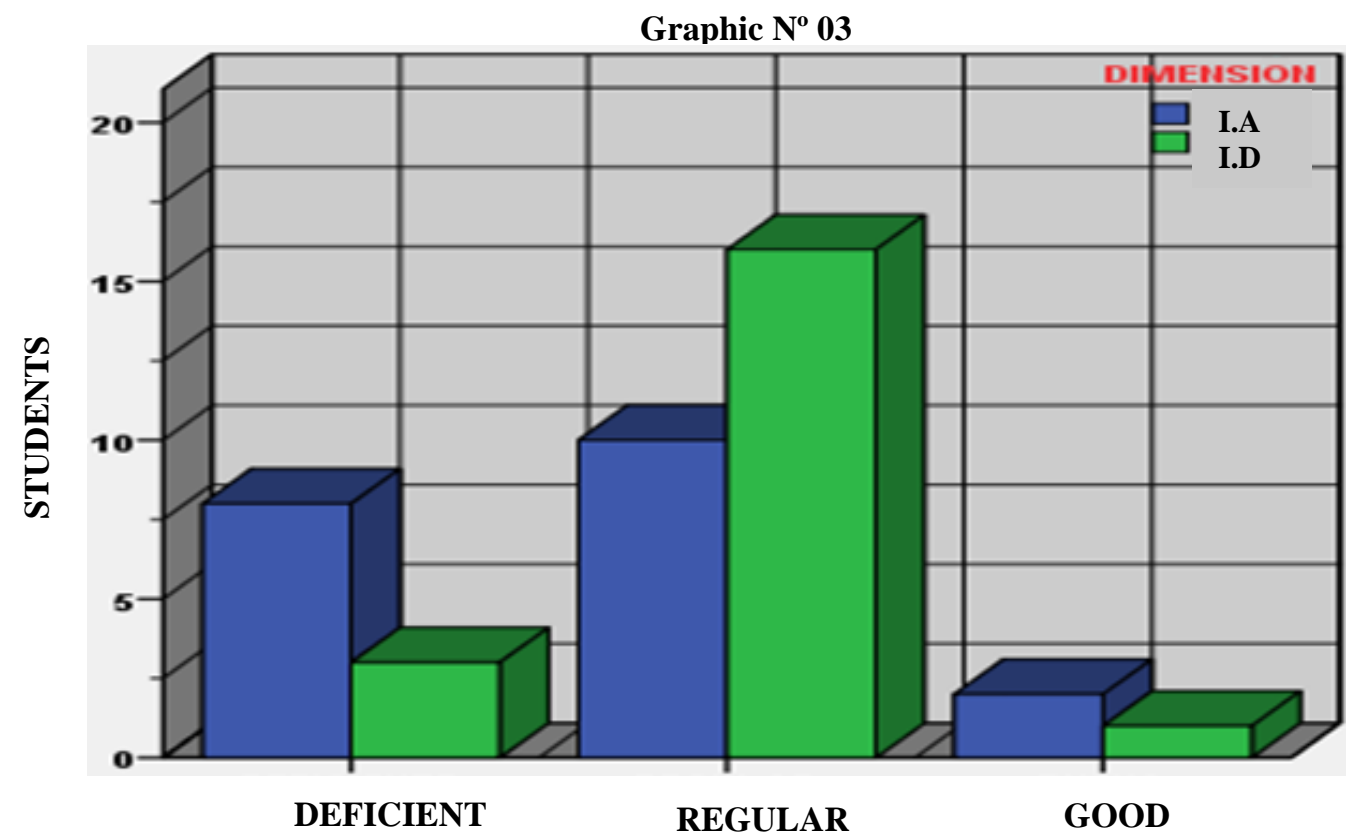


Determination of the normal distribution, we have the hypotheses:

$\mathrm{H}_{1}: \square_{\mathrm{E}} \neq \square_{\mathrm{C}}$. The two independent samples (Control and Experimental Group) do not have the same normal distribution.

$\mathrm{H}_{0}: \square_{\mathrm{E}}=\square_{\mathrm{C}}$. The two independent samples (Control and Experimental Group) have the same normal distribution.

\begin{tabular}{|c|c|c|}
\hline \multicolumn{2}{|c|}{ PARAMETRIC TEST } \\
\hline RANDOM VARIABLE & NUMERICAL \\
FIXED VARIABLE & \\
\hline Cross-sectional study independent samples & Two groups & Student's T (independent samples) \\
\hline
\end{tabular}

\section{NORMALITY}

a. $\mathrm{P}-$ Value $\geq \alpha, \mathrm{H} 0$ is accepted: the variances are equal.

b. P-Value $<\alpha$ is accepted H1: There are significant differences between the variances.

\begin{tabular}{|l|l|l|}
\hline \multicolumn{3}{|c|}{ NORMALITY } \\
\hline P-Value (Control group) $=0.06$ & $>$ & $\square=0.05$ \\
\hline P- Value (Experimental group) $=0.05$ & $\geq$ & $\square=0.05$ \\
\hline
\end{tabular}

Conclusion: $\mathrm{H}_{0}$ is accepted. The rating variable in both groups behaves normally.

\section{EQUALITY OF VARIANCE}

a. $\mathrm{P}-$ Value $\geq \alpha, \mathrm{H}_{0}$ is accepted: the variances are equal.

b. P-Value $<\alpha$ is accepted $\mathrm{H}_{1}$ : There are significant differences between the variances. 
Table $\mathrm{n}^{\circ}$ 25: QUALIFICATION OBTAINED IN THE POST-TEST OF THE CONTROL AND EXPERIMENTAL GROUP OF THE STUDENTS OF THE VOCATIONAL TRAINING SCHOOL OF FOOD INDUSTRIES ENGINEERING OF THE UNIVERSIDAD NACIONAL AGRARIA LA MOLINA, 2018-II

\begin{tabular}{|c|c|c|c|c|c|c|c|c|c|c|c|c|c|c|}
\hline \multirow{2}{*}{ 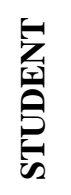 } & \multicolumn{7}{|c|}{ CONTROL GROUP } & \multicolumn{7}{|c|}{ EXPERIMENTAL GROUP } \\
\hline & P1 & P2 & P3 & P4 & P5 & P6 & $\frac{2}{2}$ & P1 & $\mathbf{P 2}$ & P3 & P4 & P5 & P6 & $\frac{\dot{\alpha}}{x}$ \\
\hline 01 & 12 & 12 & 11 & 11 & 13 & 12 & 12 & 10 & 11 & 11 & 11 & 13 & 13 & 13 \\
\hline 02 & & 11 & & 12 & 11 & & & 12 & 13 & 14 & 13 & 15 & & 14 \\
\hline 03 & & 10 & 00 & 10 & 13 & & & 11 & 14 & 14 & 13 & 15 & 14 & 14 \\
\hline 04 & 10 & 11 & 11 & 11 & 13 & 10 & 10 & 12 & 12 & 15 & 13 & 15 & 14 & 14 \\
\hline 05 & 7 & 10 & 9 & 11 & 12 & 1 & 10 & 15 & 15 & 15 & 16 & 16 & 16 & 16 \\
\hline 06 & & 13 & 13 & 13 & 14 & & & & 15 & & 18 & 18 & 17 & 17 \\
\hline 07 & 1 & 11 & 13 & 12 & 12 & 1 & 2 & 14 & 16 & 14 & 14 & 14 & 15 & 15 \\
\hline 08 & & 12 & 13 & 13 & 12 & & & 15 & 15 & & 16 & 16 & & 16 \\
\hline 09 & 12 & 13 & 14 & 13 & 15 & 1 & 4 & 14 & 16 & 14 & 14 & 14 & 15 & 15 \\
\hline 10 & & 12 & & 12 & 14 & & & 12 & 13 & 14 & 13 & 15 & 11 & 14 \\
\hline 11 & & 11 & 12 & 11 & 13 & 14 & & 11 & 12 & 13 & 13 & 12 & 14 & 13 \\
\hline 12 & & 16 & 14 & 14 & 14 & 15 & & 7 & 0 & 10 & 11 & 11 & 12 & 10 \\
\hline 13 & 15 & 15 & 15 & 16 & 16 & 10 & 16 & 15 & 15 & 15 & 16 & 16 & 16 & 16 \\
\hline 14 & 12 & 13 & 13 & 14 & 14 & 15 & 4 & 16 & 15 & 18 & 18 & 19 & 20 & 18 \\
\hline 15 & 12 & 13 & 14 & 13 & 15 & 14 & 14 & 12 & 13 & 14 & 13 & 15 & 14 & 14 \\
\hline 16 & 11 & 12 & 13 & 12 & 13 & 14 & 13 & 15 & 15 & 15 & 16 & 16 & 16 & 16 \\
\hline 17 & 09 & 10 & 10 & 10 & 11 & 13 & 11 & 11 & 11 & 12 & 11 & 13 & 14 & 12 \\
\hline 18 & 7 & 9 & 10 & 11 & 11 & 12 & 10 & 10 & 10 & 10 & 10 & 10 & 13 & 11 \\
\hline 19 & 5 & 8 & Q & 09 & 10 & 10 & & 12 & 13 & 14 & 13 & 15 & 14 & 14 \\
\hline 20 & 11 & 12 & 12 & 13 & 13 & 14 & 13 & 14 & 16 & 14 & 14 & 14 & 15 & 15 \\
\hline
\end{tabular}


Graphic N०04

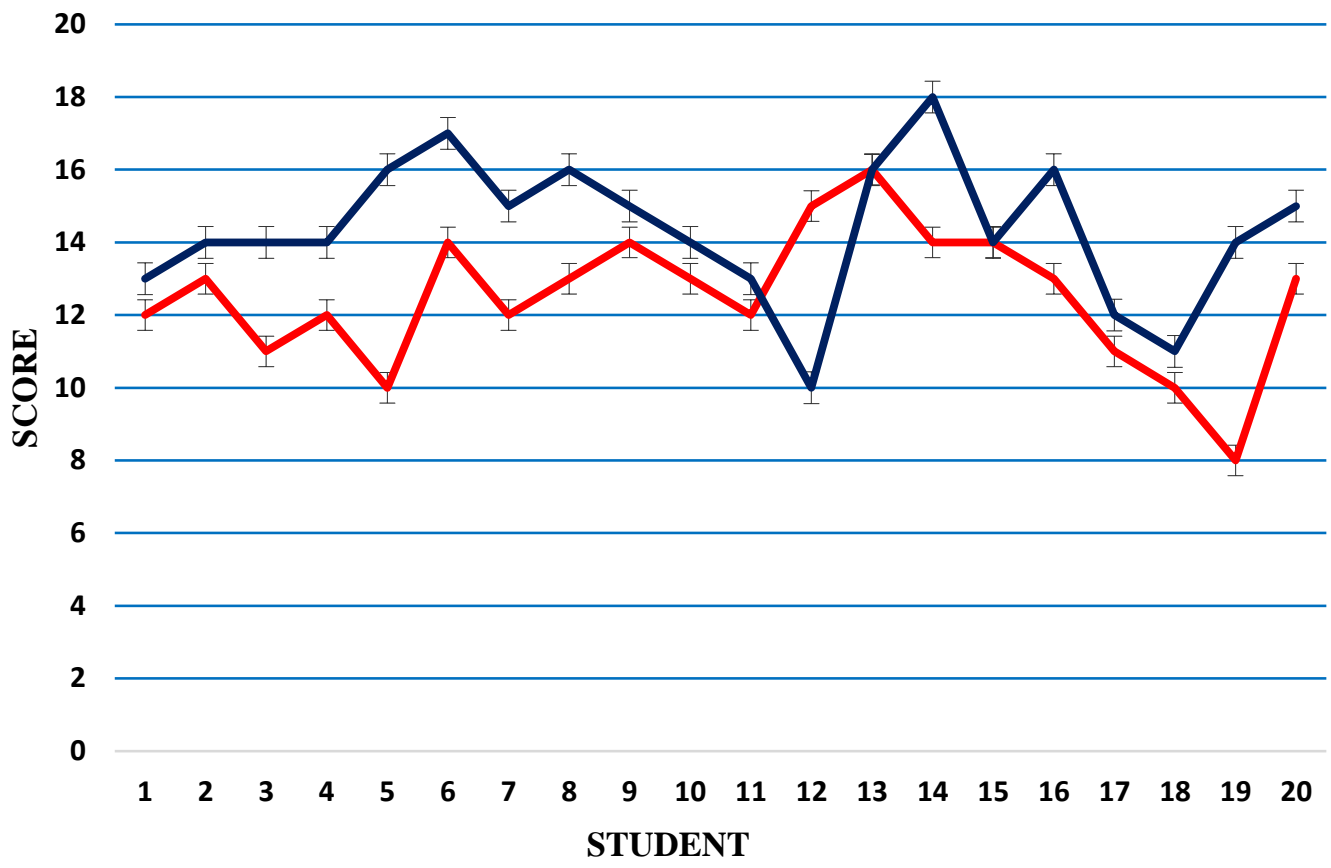

POST-TEST G.C $\longrightarrow$ POST-TEST G.E

Table N²6: STATISTICS OBTAINED IN THE POST-TEST OF THE G.C AND G.E

\begin{tabular}{|l|c|c|c|}
\hline \multicolumn{2}{|l|}{ STATISTICAL } & G. CONTROL & G. EXPERIMENTAL \\
\hline $\mathrm{N}^{\circ}$ & Valid & 20 & 20 \\
\hline \multicolumn{2}{|c|}{ Average $(\overline{\mathrm{X}})$} & 12.50 & 14.35 \\
\hline \multicolumn{2}{|c|}{ Median $\left(\mathrm{M}_{\mathrm{e}}\right)$} & 13 & 14 \\
\hline \multicolumn{2}{|c|}{ Moda $\left(\mathrm{M}_{0}\right)$} & 13 & 14 \\
\hline \multicolumn{2}{|c|}{ Dev. typ. $(\mathrm{S})$} & 1.878 & 1.954 \\
\hline \multicolumn{2}{|c|}{ Variance $\left(\mathrm{S}^{2}\right)$} & 3.526 & 3.818 \\
\hline Minimum $\left(\mathrm{X}_{\mathrm{m}}\right)$ & 08 & 10 \\
\hline \multicolumn{2}{|c|}{ Maximum $\left(\mathrm{X}_{\mathrm{M}}\right)$} & 16 & 18 \\
\hline
\end{tabular}

Table $n^{\circ}$ 27: ASSESSMENT OF POST-TEST LEARNING OF DIMENSIONS WITH ANALOGUE (I.A) AND DIGITAL (I.D) INSTRUMENT MEASUREMENTS

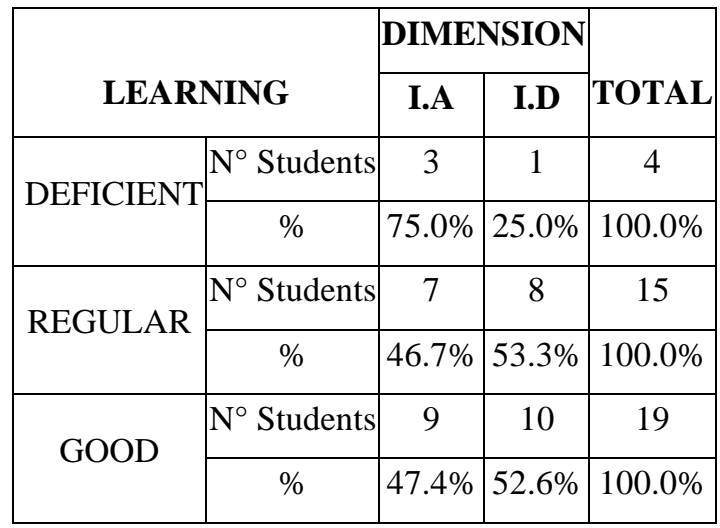




\begin{tabular}{|c|c|c|c|c|}
\hline \multirow{2}{*}{ EXCELENT } & $N^{\circ}$ Students & 1 & 1 & 2 \\
\cline { 2 - 5 } & $\%$ & $50.0 \%$ & $50.0 \%$ & $100.0 \%$ \\
\hline \multirow{2}{*}{ TOTAL } & $N^{\circ}$ Students & 20 & 20 & 40 \\
\cline { 2 - 5 } & $\%$ & $50.0 \%$ & $50.0 \%$ & $100.0 \%$ \\
\hline
\end{tabular}

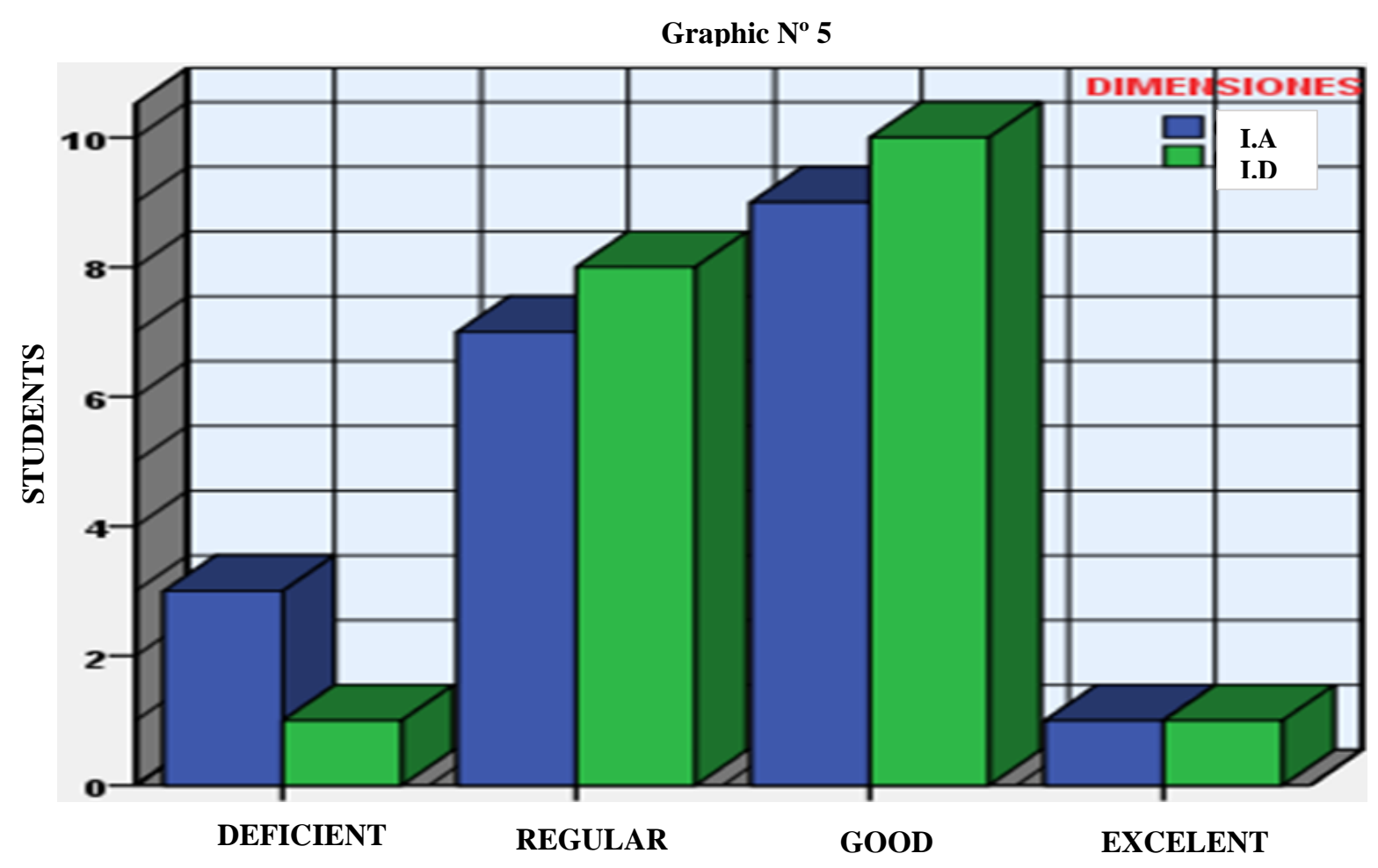

\section{NORMALITY TEST OF THE CONTROL AND EXPERIMENTAL GROUP PRE-TEST DATA}

Prueba de Hipótesis

Existirá una diferencia significativa entre

$\mathrm{H}_{1}: \square_{\mathrm{E}} \neq \square_{\mathrm{C}}$

$\mathrm{H}_{0}: \square \mathrm{E}=\square \mathrm{C}$.

\section{NORMALITY}

a. P-Value $\geq \alpha, \mathrm{H} 0$ is accepted: the variances are equal.

b. P-Value $<\alpha$ is accepted H1: There are significant differences between the variances. 


\begin{tabular}{|l|l|l|}
\hline P-Value (Control group) $=0.200$ & $>$ & $\square=0.05$ \\
\hline P- Value (Experimental group) $=0.093$ & $>$ & $\square=0.05$ \\
\hline
\end{tabular}

\section{EQUALITY OF VARIANCE}

\begin{tabular}{|l|l|l|}
\hline \multicolumn{2}{|c|}{ EQUALITY OF VARIANCE } \\
\hline P-Value $=0.926$ & $>$ & $\square=0.05$ \\
\hline
\end{tabular}

Conclusion: $\mathrm{H}_{0}$ is accepted: so the variances are equal

We calculate P-Value of the test or significance.

$$
\begin{array}{|l|l|l|}
\hline \mathrm{P}-\text { Value }=0.004 & < & \square=0.05 \\
\hline
\end{array}
$$

$\mathrm{P}$-Value $<\alpha, \mathrm{H}_{1}$ is accepted: There are significant differences between the mean scores.

Conclusion: There is a significant difference in the mean scores of the Control and Experimental Group

\section{Graphic $\mathbf{N}^{\circ} 6$}

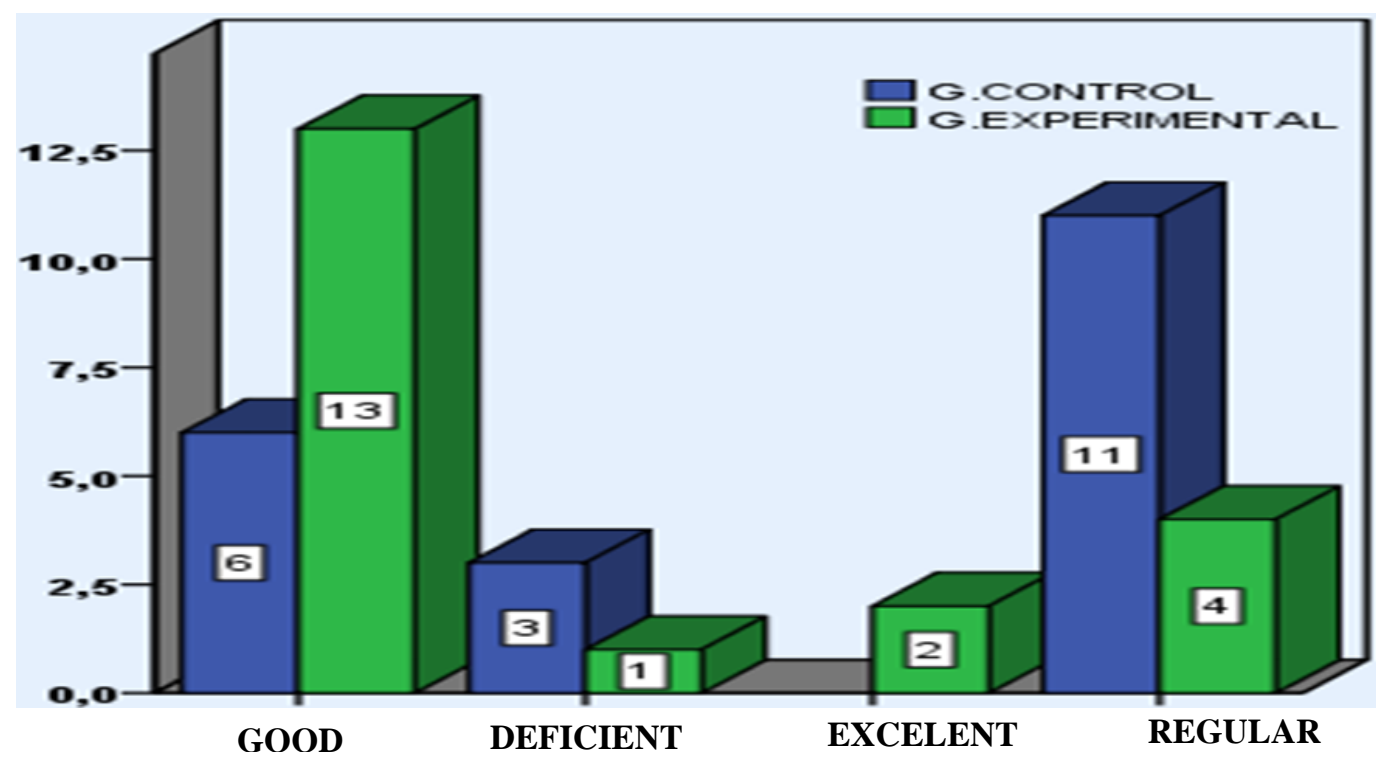

Table N $\mathrm{N}^{\circ}$ 28: APPROVED AND DISAPPROVED BY THE CONTROL AND EXPERIMENTAL GROUP AFTER THE TEACHING STRATEGY OF THE STUDENTS OF THE PROFESSIONAL SCHOOL OF FOOD INDUSTRIES ENGINEERING OF THE UNIVERSIDAD NACIONAL AGRARIA LA MOLINA, 2018-II

\begin{tabular}{|c|c|c|c|c|c|}
\hline \multicolumn{2}{|c|}{ ACADEMIC PERFORMANCE } & \multicolumn{2}{c|}{ GROUPS } & \multirow{2}{*}{ TOTAL } \\
\cline { 3 - 6 } & \multirow{3}{*}{ APPROVED } & $\mathrm{N}^{\circ}$ Students & 17 & 19 & 36 \\
\cline { 3 - 6 } & $\%$ LEARNING & $47,2 \%$ & $52,8 \%$ & $100,0 \%$ \\
\hline \multirow{3}{*}{ LEARNING } & \multirow{2}{*}{ DISAPPROVED } & $\mathrm{N}^{\circ}$ Students & 3 & 1 & 4 \\
\cline { 3 - 6 } & $\%$ LEARNING & $75,0 \%$ & $25,0 \%$ & $100,0 \%$ \\
\hline \multicolumn{2}{|c|}{ TOTAL } & $\mathrm{N}^{\circ}$ Students & 20 & 20 & 40 \\
\hline
\end{tabular}




\begin{tabular}{|l|l|l|l|}
\hline$\%$ LEARNING & $50,0 \%$ & $50,0 \%$ & $100,0 \%$ \\
\hline
\end{tabular}

COMPARISON OF THE GRADES OBTAINED IN THE PRE-TEST BY THE G.C AND POSTTEST BY THE G.E

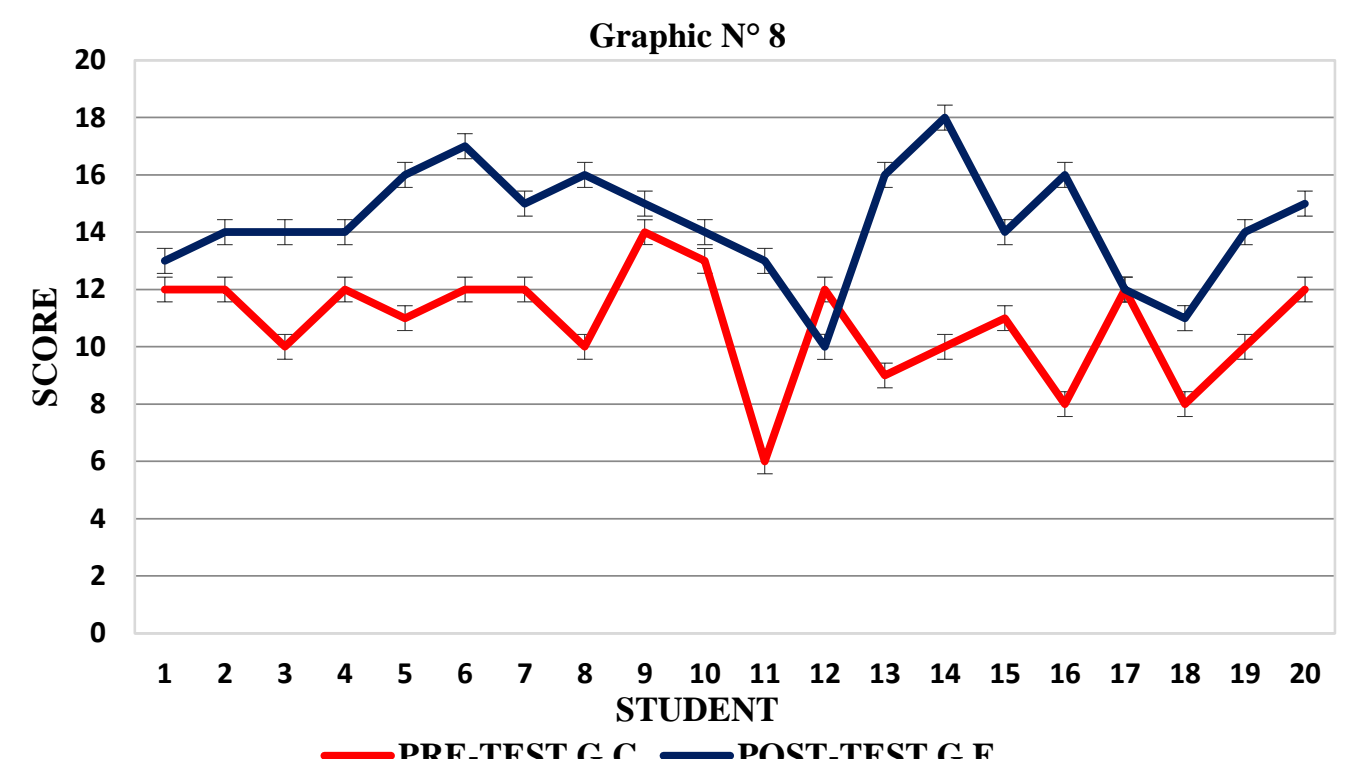

COMPARISON OF THE RATINGS OBTAINED IN THE PRE-TEST BY THE G.E and POSTTEST BY THE G.E. 
GRAPHIC $\mathbf{N}^{\circ} 9$

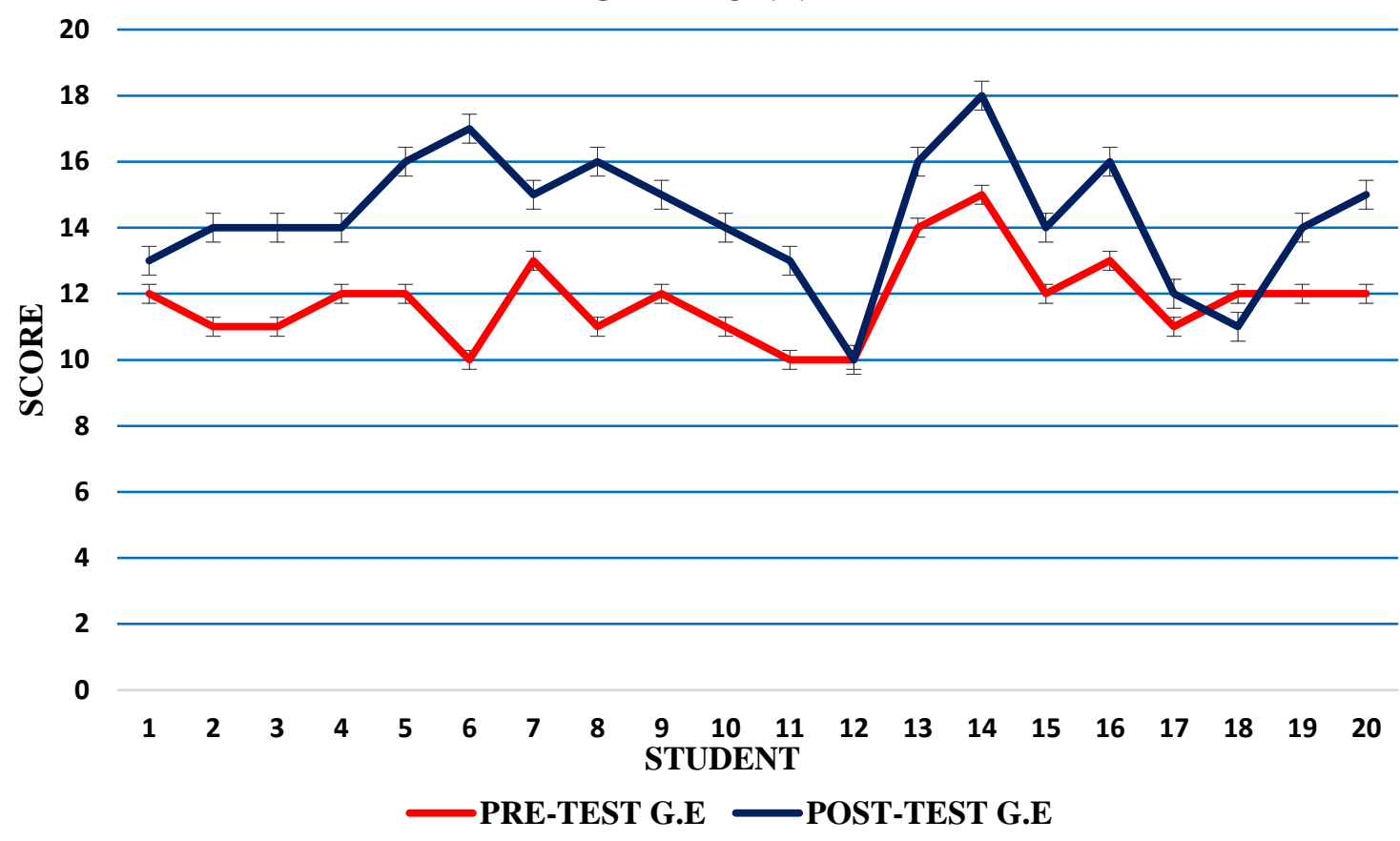

Graphic No 7

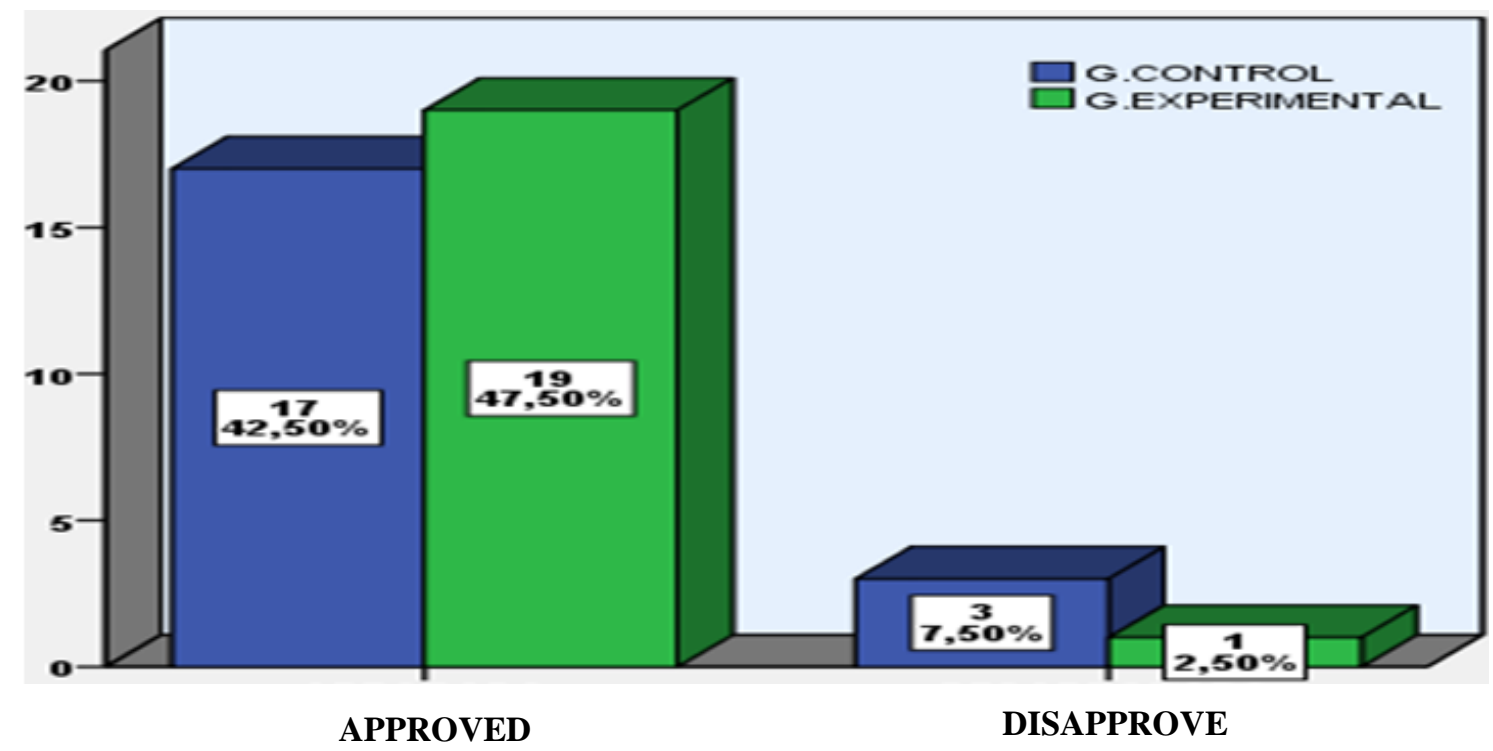


STATISTICAL RESULTS OF THE DIMENSIONS ACCORDING TO THE INDICATORS OF THE SPECIFIC HYPOTHESES

Table $\mathrm{N}^{\circ}$ 29: ASSESSMENT OF THE RATINGS OBTAINED IN THE PRE-TEST AND POST-TEST OF ELECTRIC CIRCUITS.

\begin{tabular}{|c|c|c|}
\hline \multicolumn{3}{|c|}{ ELECTRICAL CIRCUIT: MEASUREMENT WITH ANALOGICAL INSTRUMENTS $($ I.A) } \\
\hline ASSESSMENT & $\mathbf{N}^{\circ}$ STUDENTS PRE-TEST & $\mathbf{N}^{\circ}$ STUDENTS POST-TEST \\
\hline DEFICIENT & 3 & 1 \\
\hline REGULAR & 16 & 8 \\
\hline GOOD & 1 & 10 \\
\hline EXCELENT & 0 & 1 \\
\hline
\end{tabular}

Graphic No 10 QUALIFICATIONS OBTAINED IN THE MEASUREMENT TEST WITH ANALOGICAL INSTRUMENTS

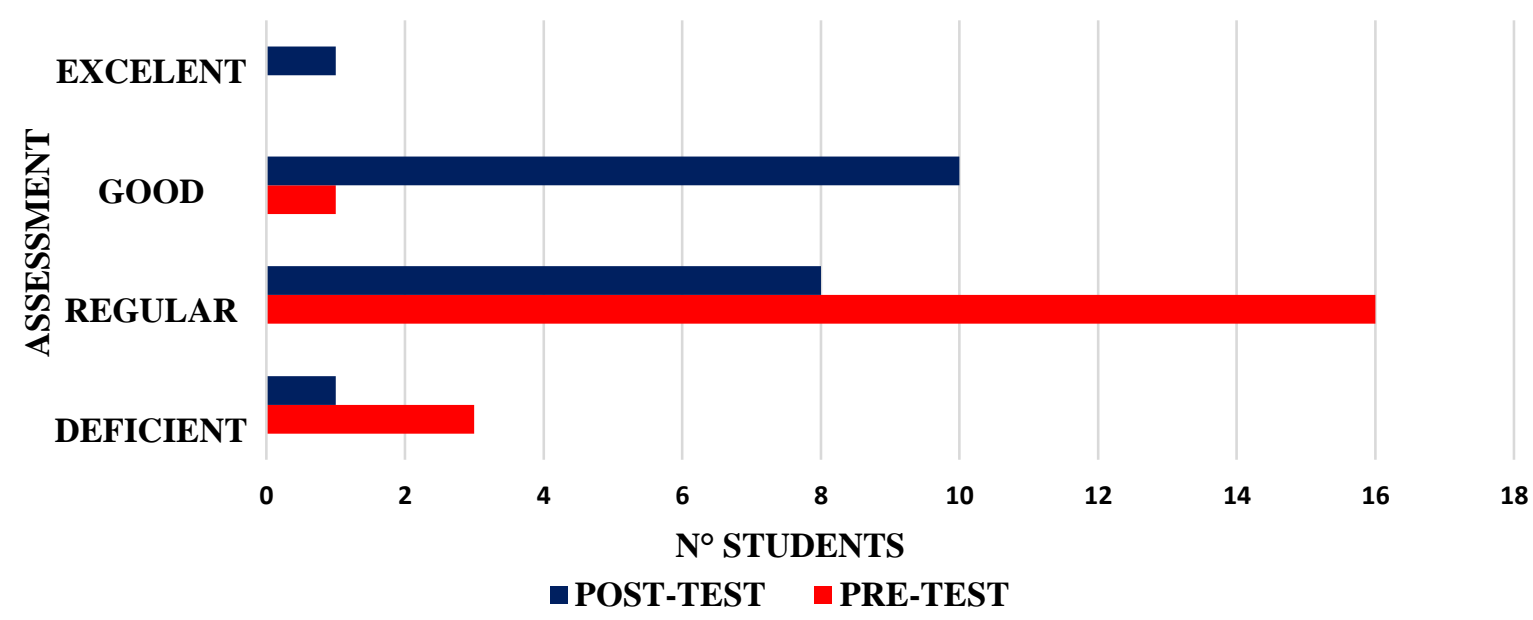

Table $\mathrm{N}^{\circ}$ 30: ASSESSMENT OF THE RATINGS OBTAINED IN THE PRE-TEST AND POST-TEST OF ELECTRIC CIRCUITS

\begin{tabular}{|c|c|c|}
\hline \multicolumn{3}{|c|}{ ELECTRICAL CIRCUIT: MEASUREMENT WITH DIGITAL INSTRUMENTS (I.D) } \\
\hline ASSESSMENT & $\mathbf{N}^{\circ}$ STUDENTS PRE-TEST & $\mathbf{N}^{\circ}$ STUDENTS POST-TEST \\
\hline DEFICIENT & 8 & 3 \\
\hline REGULAR & 10 & 7 \\
\hline GOOD & 2 & 9 \\
\hline EXCELENT & 0 & 1 \\
\hline
\end{tabular}




\section{GRAPH N $^{\circ} 11$ QUALIFICATIONS OBTAINED IN THE MEASUREMENT TEST WITH DIGITAL INSTRUMENTS}

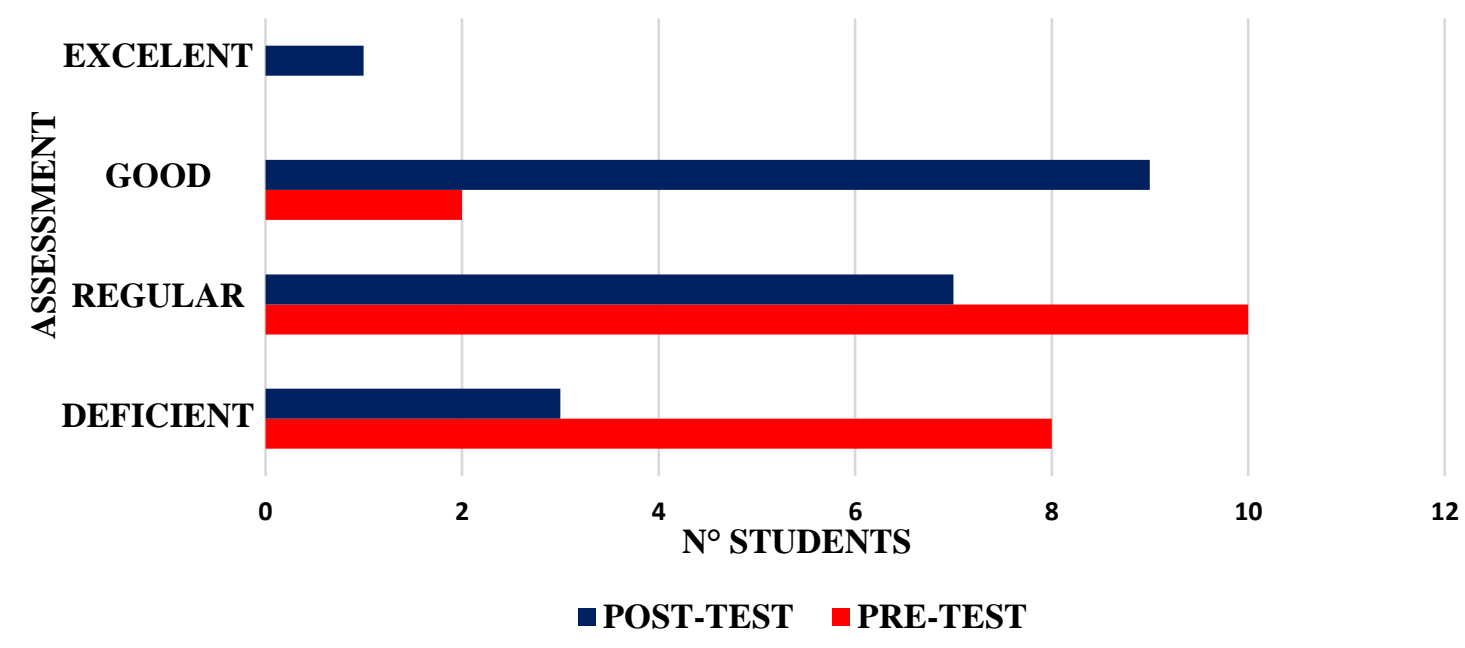

\section{CONCLUSION}

It was found that there is a significant difference produced by pedagogical habitability, with light illumination with fluorescent lamps with respect to the group of students who work with light illumination with LED devices, in the learning of the Electrical Circuits course of the Professional School of Engineering of Food Industries VI cycle of UNALM, 2018-II, as the results shown in this investigation are recorded.

It was possible to determine that there is a significant difference produced by the illumination of light with fluorescent lamps, with respect to LED devices, in the measurement process with analog instruments for the learning of the Electrical Circuits course in the students of the School Food Industries Engineering Professional VI cycle of UNALM, 2018-II, as recorded by the results of the investigation

It was possible to determine the significant difference produced by the illumination of the light with fluorescent lamps, with respect to the LED devices, in the measurement process with digital instruments for the learning of the course of electrical circuits in the students of the Professional School of Food Industries Engineering cycle VI of UNALM, 2018-II, as recorded by the results of the investigation.

The average qualification of the students of the Experimental Group is much higher than that of the students of the Control Group, in the teaching of Electric Circuits, due to various factors, which generated greater disposition and interest in learning according to technological and scientific advances giving Emphasis on the achievement of meaningful learning, through empathy, motivation and interrelation with the teacher, leaving aside traditional teaching, based on the interview data in the group focuses. 
The positive conclusion of the Electric Circuits teaching strategy through the use of classrooms with optimal habitability, generates a greater disposition towards learning, as affirmed by the participating students. 


\section{REFERENCES}

[1]. Alvarado, E.: Sistemas Fotovoltaícos para Iluminación: pp. 25-30. Loja, Ecuador (2010).

[2]. Arroyo, D.: Auditoria energética aplicada a la optimización de los sistemas de iluminación en un modelo de aula de la escuela superior de arquitectura de Valladolid: pp. 21-25. Valladolid, España (2016).

[3]. Boylestad, L.: Introducción al Análisis de Circuitos: 10ma ed., pp. 100-125. Editorial Pearson Educación, México (2011).

[4]. Bruner, J.: Investigaciones sobre el desarrollo cognoscitivo: 1ra ed., pp. 48-55. Editorial Pablo del Rio, España (1980).

[5]. Ausubel, D.: Psicología Educativa: 2da ed., pp. 15-25. Editorial Trillos, México (1983).

[6]. Pesantes, P.: Diseño de un Sistema de Optimización de energía eléctrica para iluminación en sectores críticos de la Universidad Politénica Salesiana, sede matriz Cuenca: pp. 40-60. Cuenca, Ecuador (2014).

[7]. Rebolloso, E.: Criterios de Calidad Ambiental para la Evaluación de Aulas Universitarias: pp. 8595. Andalucía, España (2002).

[8]. Ramirez, T.: Como hacer un Proyecto de Investigación: pp. 45-52. Panapo de Venezuela, C.A., Venezuela (1999).

[9]. Hernandez, T.: Metodología de la Investigación: pp. 20-25. Mc Graw Hill, México (2003). 